\title{
Mobility and home-range use of Atlantic salmon parr over short time scales
}

\author{
Michaël Ovidio $^{1 \text { a }}$, Eva C. Enders ${ }^{2}$, Eric J. Hallot ${ }^{3}$, Mathieu L. Roy ${ }^{4}$, Jean-Claude Philippart ${ }^{1}$, \\ François Petit ${ }^{3}$ and André G. Roy ${ }^{4}$ \\ ${ }^{1}$ University of Liège, Biology of Behaviour Unit, Laboratory of Fish Demography and Hydroecology, 10 Chemin de la Justice, 4500 Tihange, \\ Belgium \\ 2 Fisheries and Oceans Canada, Ecological Sciences Section, 80 East White Hills Road, PO Box 5667, St. John's, NL, A1C 5X1, Canada \\ ${ }^{3}$ University of Liège, Hydrology and Fluvial Geomorphology Research Center, 2 Allée du 6 août, 4000 Liège, Belgium \\ ${ }^{4}$ Université de Montréal, Département de Géographie, Chaire de recherche du Canada en dynamique fluviale, CP 6128, Succursale \\ "Centre-Ville", Montréal, Québec, H3C 3J7, Canada
}

Received 15 September 2006; Accepted 15 December 2006

\begin{abstract}
This study performed in the Patapédia River (Québec, Gaspésie) was designed to examine the space utilization and mobility patterns of individual Atlantic salmon parr over short time scales with frequent detections of position. In August 2004, $n=7$ radio-tagged Atlantic salmon parr were located every 20 min during 10 tracking periods chosen to take into account the dawn, day, dusk and night periods. Parr showed important inter individual variability in space utilization and mobility patterns, occupying large home ranges (123 to $5602 \mathrm{~m}^{2}$ ) and sometimes migrating $2 \mathrm{~km}$ upstream in the river. No differences were observed in the mean distance travelled among the four daily periods by individual fish, but the estimated home ranges utilized during the four daily periods overlapped only partially, demonstrating that parr partly occupy different areas of the river during different parts of the daily cycle. The results suggest that an intense survey on a small number of fish may contribute to a complementary comprehension of space utilization and mobility patterns of Atlantic salmon parr when viewed in association with results from studies surveying larger number of fish at lower frequency.
\end{abstract}

Key words: Tracking / Home range / Radio-telemetry / Atlantic salmon parr / Salmo salar / Canada

\section{Introduction}

Atlantic salmon parr (the stage after yolk sac absorption and before migration to sea) are generally considered to move only over short distances and to use restricted territories in rivers (Kalleberg 1958; Keenleyside and Yamamoto 1961; Gibson 1993). In contrast, Armstrong et al. (1994) demonstrated by removal experiments that at least in some systems, long-range movements appear to be transient and seasonal. Recent studies of large salmon parr fitted with radio tags in rivers $>10 \mathrm{~m}$ wide (Økland et al. 2004; Robertson et al. 2004) have recorded daily movements extending to several hundred metres. For example, under summer conditions, Økland et al. (2004) observed mean movements of $402 \mathrm{~m}$ for parr in the River Alta, Norway over a period of 14 days. Similarly, Robertson et al. (2004) reported that parr in the West Salmon River, Newfoundland, Canada may move distances of over

\footnotetext{
a Corresponding author: M.Ovidio@ulg.ac.be
}

$300 \mathrm{~m}$ during the winter. However, these studies have located fish only 1-4 times per day and provide no insight into movement and home range use over shorter time scales and during day/night alternation. We used an intensive tracking protocol on a small number of individuals to: (1) examine patterns of space utilization of individual Atlantic salmon parr; (2) document variations in movement as a function of the period of the day; and (3) test the effects of tracking interval on estimates of home range size.

\section{Material and methods}

The study was conducted from 18 to 29 August 2004 on the Patapédia River in Québec, Canada (Fig. 1). The Patapédia is a gravel-bed river characterized by riffle-pool sequences. At the study site, mean channel width was $30 \mathrm{~m}$ and water depth was up to $3 \mathrm{~m}$ in pools. Surface bed material was predominantly a mixture of cobbles and boulders. During the study period, 


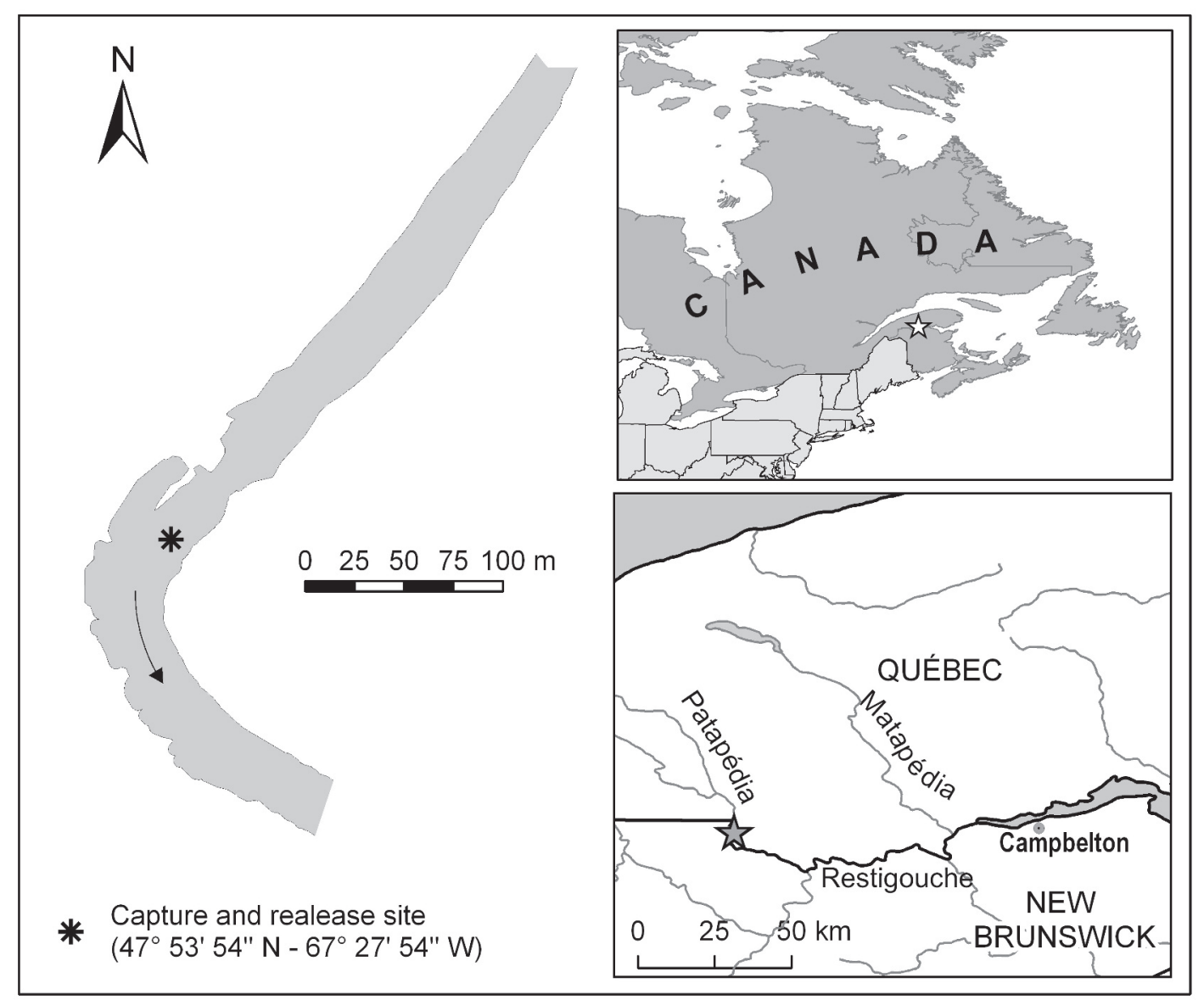

Fig. 1. Location of the study site in Patapédia River, Québec, Canada $\left(47^{\circ} 53^{\prime} 54^{\prime \prime} \mathrm{N} ; 67^{\circ} 27^{\prime} 54^{\prime \prime} \mathrm{W}\right)$.

water temperatures ranged from 10.1 to $13.9^{\circ} \mathrm{C}$ and the mean discharge was estimated at $8.5 \mathrm{~m}^{3} \mathrm{~s}^{-1}$. Before the study period, a high flow event occurred between 11 and 17 August 2004 (up to $80 \%$ bankfull discharge). The experiment started when the water was stabilized.

Atlantic salmon parr were captured by electrofishing (model 12-B, Smith-Root) on the $18^{\text {th }}(n=6)$ and $22^{\text {nd }}$ $(n=2)$ of August 2004. No parr were identified as precociously maturing male. After capture, fish were anaesthetized in a 2-phenoxy-ethanol solution $\left(0.2 \mathrm{ml} \mathrm{L}^{-1}\right)$. Fish were then laid with their ventral side uppermost on a wetted tissue soaked with anaesthetic. A midventral incision was made $5 \mathrm{~mm}$ anterior to the pelvic girdle. A radio transmitter (model F1410; ATS Inc., Isanti, USA; $40 \mathrm{MHz}$, trailing whip antenna of $210 \mathrm{~mm}, 1.0 \mathrm{~g}$ in air, $0.6 \mathrm{~g}$ in water, $7 \times 15 \mathrm{~mm} 10$ days of battery life) was inserted through the incision. For all eight tagged fish, the "tag mass/body mass" ratio was less than $3.8 \%$ (Table 1). The transmitter antenna was threaded through the body wall using a hollow needle approximately $5 \mathrm{~mm}$ posterior of the incision. The incision was closed with two independent sutures (Vycril 5/0, 3/8c). Individual surgery took between 3-5 min. Tagged fish were allowed a short recovery in a tank for $15 \mathrm{~min}$ before being released as close as possible to their capture site (max. $15 \mathrm{~m}$ away). This short recovery period was chosen to reduce potential effects from postoperative care and to replace the fish in their environment as soon as possible. Fish were not tracked for the first 24-h period after their release to avoid biased observations reflecting a potential traumatic state just after capture and tagging. Detailed data collection was obtained for seven parr as one rapidly left the study area after release.

A map of the river's banks and the river edges was completed before fish tracking using a tacheometric station (TC-805L; Leica Geosystems AG, Heerbrugg, Switzerland). From the 20 to 26 August 2004, all the fish were located three times per hour during a maximum of 10 tracking surveys conducted at two different time periods [ $(n=5$ from 3:00 to 8:00 during night, dusk and day periods) and ( $n=5$ from 17:00 to 22:00 during day, dusk and night periods)]. Each parr was thus located 30 times per daily cycle. Each fish was located simultaneously by three different observers using FieldMasters ${ }^{\mathrm{TM}}$ radio receivers and directional loop antennas (ATS Inc., Isanti, USA) from three spatially referenced landmarks (a total of 43 stakes were placed $10 \mathrm{~m}$ apart in the study site) equipped with a fixed north oriented graduated circle $\left( \pm 0.5^{\circ}\right)$. The three observers could determine the compass bearing of the parr using the variation of the power of the radio signal, the fish direction corresponding to the minimum signal strength (null peak). The three azimuths were immediately transmitted by radio to the encoding crew, which used a customized software 
Table 1. Capture and release date, fork length, body mass, tag to body mass ratio, number of days tracked during the study site (d), mean distance traveled $\left(D, \mathrm{~m} \mathrm{~min}^{-1}\right), 95 \%$ kernel home ranges sizes $\left(\mathrm{m}^{2}\right)$ for eight radio-tracked Atlantic salmon parr.

\begin{tabular}{|c|c|c|c|c|c|c|c|}
\hline $\begin{array}{c}\text { Fish } \\
\#\end{array}$ & $\begin{array}{l}\text { Capture and } \\
\text { release } \\
\text { date }\end{array}$ & $\begin{array}{l}\text { Fork } \\
\text { length } \\
(\mathrm{mm})\end{array}$ & $\begin{array}{l}\text { Body } \\
\text { mass } \\
(\mathrm{g})\end{array}$ & $\begin{array}{c}\text { Tag ratio } \\
(\%)\end{array}$ & $\begin{array}{l}\text { Day } \\
\text { tracked } \\
\text { (d) }\end{array}$ & $\begin{array}{c}D \\
\left(m \min ^{-1} \pm \mathrm{SD}\right) \\
95 \%\end{array}$ & $\begin{array}{c}\text { Home } \\
\text { range } \\
\left(\mathrm{m}^{2}\right)\end{array}$ \\
\hline 1 & 18 August 2004 & 133 & 31.4 & 3.2 & 5 & $0.41 \pm 0.31$ & 5602.3 \\
\hline 2 & 18 August 2004 & 143 & 36.2 & 2.8 & 5 & $0.37 \pm 0.30$ & 374.7 \\
\hline 3 & 18 August 2004 & 143 & 33.0 & 3.0 & 2 & $0.75 \pm 0.66$ & 2714.1 \\
\hline 4 & 18 August 2004 & 143 & 31.7 & 3.2 & 5 & $0.20 \pm 0.21$ & 123.4 \\
\hline 5 & 18 August 2004 & 131 & 28.4 & 3.5 & 0 & - & - \\
\hline 6 & 18 August 2004 & 134 & 26.5 & 3.8 & 3 & $0.65 \pm 0.48$ & 1413.3 \\
\hline 7 & 22 August 2004 & 135 & 29.3 & 3.4 & 3 & $0.32 \pm 0.30$ & 304.9 \\
\hline 8 & 22 August 2004 & 128 & 29.5 & 3.4 & 3 & $0.53 \pm 0.75$ & 1738.0 \\
\hline
\end{tabular}

(FishTracker, Hallot et al. personal development) to calculate and map fish positions by means of a triangulation calculation. As the measured error was the same for the three azimuths, the most accurate position was defined as the center of gravity of the triangle (the mean of the three coordinates).

Fish locations were mapped using ArcMap 8.2. Distances between two consecutive fish locations were calculated. To take into account the differences in duration between the determination of fish locations, the movements were standardized to distance travelled per min (hereafter referred to as "mean distance travelled"). These are in effect minimum distances, as parr could have moved between successive determinations of position. Distances from the last location at 08:00 and the first location at 17:00 were excluded from the analyses. For each fish, the mean distances traveled during dusk, day, dawn and night periods were estimated. The "Animal Movement" extension of ArcView 3.2 was used to determine the home ranges of parr (Hooge and Eichenlaub 2000). The fixed kernel method was chosen as suggested by the study of Økland et al. (2004). This software calculated a "fixed kernel home range utilization distribution" (Worton 1989) as a grid coverage using an ad hoc calculation of a smoothing parameter (h) by the least squares cross validation (Silverman 1986). Kernel home ranges were estimated for a $95 \%$ probability of fish presence for the entire study period. Additionally, home ranges ( $95 \%$ probability) were calculated for the dusk, day, dawn and night periods for each fish. ArcView 3.2 was also used to calculate the percentage of shared surfaces of the $95 \%$ home ranges between each period of the daily cycle and between the four periods for each parr. In order to test the effects of the relocation frequency on home range estimation, our data set was sub sampled as if the parr were located as followed: (1) Two locations per day at 7:00 and 17:00 and (2) six locations per day including the four periods of the daily cycle at 3:00, 5:00, 7:00, 17:00, 19:00 and 21:00. Home ranges ( $95 \%$ probability) were calculated and compared to those obtained with 30 locations per day.

\section{Results}

One of the eight tagged Atlantic salmon parr (\#5) was not detected after the first tracking survey and was not found despite an intensive search over several kilometers of the river both upstream and downstream from the release point. This fish was not considered for further analysis. For the remaining parr, three different spatial utilization patterns were observed during the study period (Fig. 2). (1) Two fish (\#2 and \#4) stayed in a restricted area close to the release site and used home ranges of 374.7 and $123.4 \mathrm{~m}^{2}$, respectively. (2) Home ranges of fish \#7 and \#8 sometimes overlap spatially and temporally in the southern-most cores of their ranges. Fish \#8 stayed during three days near the release site before moving downstream where it settled in a new area; whereas fish \#7 was first located in this area during the first tracking survey and then moved upstream to the original release site where it stayed until the end of the study period. Fish \#7 and \#8 used home ranges of 1738.0 and $304.9 \mathrm{~m}^{2}$, respectively. (3) Three fish (\#1, \#3 and \#6) moved progressively upstream during the study period. Fish \#3 and \#6 left the study site on 21 and 22 August 2004 and were last observed 1800 and $250 \mathrm{~m}$ upstream from the study site, respectively. Fish \#1 had a different behavior and stayed in the studied reach. It occupied a large home range of $5602.3 \mathrm{~m}^{2}$. Significant differences were found in the $95 \%$ home ranges at dawn, day, dusk and night among the seven parr (Kruskal-Wallis test, $p$ always $<0.05$ ). However, the comparison of the $95 \%$ home range for a given parr among the four different daily periods did not reveal any significant differences (Friedman, $p$ always $>0.05$ ).

Mean distance travelled by parr ranged from 0.20 (\#4) to $0.75(\# 3) \mathrm{m} \cdot \mathrm{min}^{-1}$ (Table 1 ) and differed significantly among individual fish (Kruskal-Wallis, $\chi^{2}=109.66$, d.f. $=6, p<$ $0.0001)$. The differences in mean distance travelled among individual fish was not be explained by body mass (simple linear regression, $n=7, r^{2}=0.14, p=0.62$ ). No significant differences were observed in the mean distance traveled between dusk, day, dawn and night periods (Friedman test, $p$ always $>0.05$ ) for any of the seven fish. However, the $95 \%$ home ranges estimated for the four periods of the daily cycle were only partially overlapping, suggesting that fish occupied somewhat different areas during dawn, day, dusk and night periods (Table 2). Mean shared surfaces between two periods ranged from $38 \%$ (dawn/dusk) to $67 \%$ (day/dusk). The common area occupied by individual fish during all four periods varied between $5 \%$ (\#7) and 50\% (\#1). Subsampling the data to a frequency of six detections per day, that included the four periods of the daily cycle $(3: 00,5: 00,7: 00,17: 00,19: 00$ and 21:00) in- 


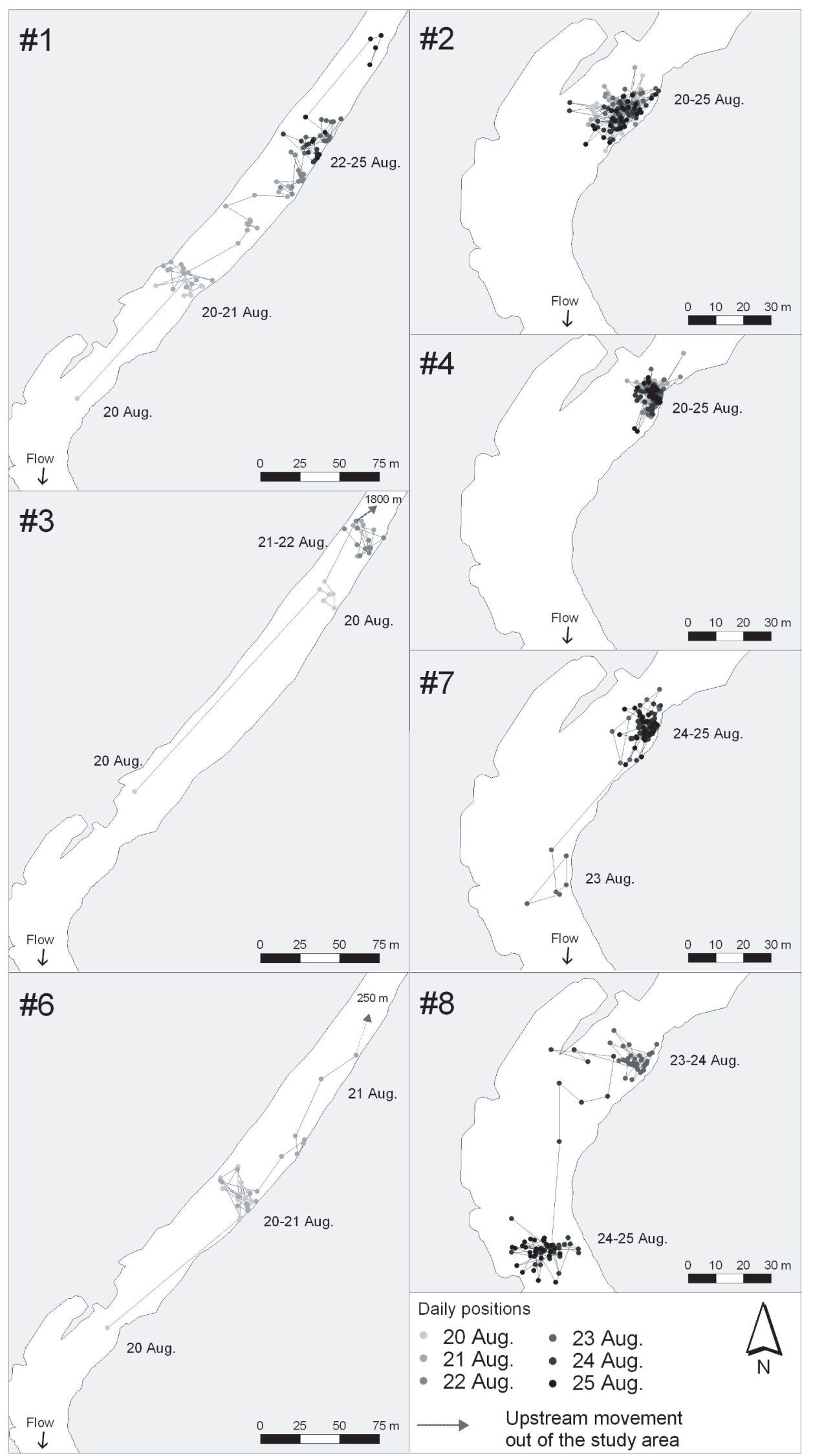

Fig. 2. Spatial representation of the locations of the seven Atlantic salmon parr radio-tracked from 20 to 26 August 2004 in the Patapédia River. 
Table 2. Percentage of shared surfaces of the $95 \%$ home ranges between each period of the daily cycle for Atlantic salmon parr radio-tracked in the Patapédia River.

\begin{tabular}{|c|c|c|c|c|c|c|c|}
\hline $\begin{array}{c}\text { Fish } \\
\#\end{array}$ & Dawn/Day & Dawn/Dusk & Dawn/Night & Day/Dusk & Day/Night & Dusk/Night & $\begin{array}{l}\text { Common for } \\
\text { all periods }\end{array}$ \\
\hline 1 & 60 & 60 & 71 & 80 & 74 & 66 & 50 \\
\hline 2 & 53 & 41 & 48 & 47 & 56 & 44 & 22 \\
\hline 3 & 48 & 27 & 46 & 84 & 20 & 15 & 9 \\
\hline 4 & 40 & 52 & 60 & 53 & 40 & 50 & 28 \\
\hline 6 & 22 & 22 & 53 & 72 & 33 & 23 & 16 \\
\hline 7 & 23 & 6 & 63 & 21 & 29 & 8 & 5 \\
\hline 8 & 56 & 60 & 66 & 78 & 61 & 65 & 46 \\
\hline Mean & 43 & 38 & 58 & 62 & 45 & 39 & 25 \\
\hline
\end{tabular}

creased the estimates of the home range sizes for parr \#1, \#4, $\# 6$, \#7 and \#8 from 5\% to $180 \%$ (mean \pm SD: $63.5 \pm 71.1 \%$ ) and decreased the size of $25 \%$ and $51 \%$ for parr \#2 and \#3, respectively.

\section{Discussion}

In this study, we used radio-telemetry to track a small number of parr during four periods of the daily cycle. In comparison to earlier studies using mark-recapture (Saunders and Gee 1964; Hesthagen 1990), visual observation (Steingrimsson and Grant 1999) or passive integrated transponder (PIT) technology (Armstrong et al. 1998; Roussel et al. 2000, 2004), radiotelemetry permitted locating fish over larger distances under a wider variety of environmental conditions. However, due to the transmitter size limitations, this methodology allows only the study of larger individual parr. Recent studies demonstrated that implanting juvenile salmonids with transmitters representing up to $12 \%$ of body weight did not affect the swimming performance of fish (Adams et al. 1998; Brown et al. 1999; Robertson et al. 2003; Lacroix et al. 2004). However, it has been suggested that the presence of a trailing whip antenna may sometimes cause changes in social status (Connors et al. 2002), predator avoidance (Adams et al. 1998) and a significant decrease in swimming performance, if its length reaches $300 \mathrm{~mm}$ (Murchie et al. 2004). In this study, in order to minimize the potential effect of the tag on parr behavior, the transmitters represented a maximum of $3.8 \%$ of the body mass and the trailing antenna measured $210 \mathrm{~mm}$.

Atlantic salmon parr showed high inter-individual variations in mobility patterns and space utilization. Three main different space utilization strategies were observed for the seven Atlantic salmon parr tracked during this study: (i) one pattern was restricted mobility in a single area occupying home ranges of 123.4 to $374.7 \mathrm{~m}^{2}$. It is important to note that these smallest home ranges are significantly larger than those observed in earlier studies conducted using the mark-recapture method (Saunders and Gee 1964, $36 \mathrm{~m}^{2}$; Hesthagen 1990, 40-50 m²). Similarly, Armstrong et al. (1999) reported smaller maximum home ranges of up to $12 \mathrm{~m}$ in length $\left(\approx 45 \mathrm{~m}^{2}\right)$, using PIT tags in a $3 \mathrm{~m}$-wide enclosed section of a natural stream. (ii) A second pattern was movements between two distinct areas with individuals occupying home ranges of up to $1738 \mathrm{~m}^{2}$, suggest- ing that parr are able to recognize and take advantage of particular river sectors (iii) The third pattern observed was a progressive upstream movement with fish occupying a river section of up to $1800 \mathrm{~m}$. Migratory movements of several hundred meters were observed between a river and a lake in Newfoundland, especially in spring-early summer (Erkinaro and Gibson 1997). Larger scale movements were also observed in the same region by Robertson et al. (2003) on a much longer temporal scale reflecting seasonal changes in parr behavior. Parr migrated approximately $2 \mathrm{~km}$ between lake and river environments in early winter (Robertson et al. 2003). In the present study, it could be that during the high flood event that occurred before the study period, some parr may have been passively displaced or may have actively searched for more suitable habitat. Consequently, the observed upstream movement of three parr (\#1, \#3 and \#6) may correspond to a return to their original home sites after displacement. As these parr moved upstream over long distances two or three days after tagging, this behavior probably does not correspond to a post-operative traumatic state. Several studies have established that parr have the capacity to return to their original home sites after being displaced over more than 200 m (Saunders and Gee 1964; Garcia de Leaniz 1989; Huntingford et al. 1998), and additional work demonstrated that parr sometimes travelled long distances during hydropeaking (Berland et al. 2004; Scruton et al. 2003). Considering this important behavioral diversity among our small sample of seven tracked parr, it may be assumed that a large variety of mobility patterns and space utilization exists in Atlantic salmon parr populations.

One of the reasons for the observed individual variability in space utilization of Atlantic salmon parr may be individual dominance status. Armstrong et al. (1999) suggested that dominant parr settle in restricted territories, which they defend from intruders whereas subdominant parr adjust their positions and movements accordingly. However, a recent experimental study suggested that parr can also be dominant and move frequently between feeding locations; but parr tend to leave rich patches less frequently than they leave poor patches (Maclean et al. 2005). In the present study, social relations of parr could not be analyzed but it may be hypothesized that parr could have held to different social status. The results demonstrated that home ranges obtained during the four daily periods are only partially overlapping and suggested that fish selected different habitats over the daily cycle, probably related to vari- 
ous biological activities (resting, feeding, social interactions) (Lucas and Baras 2001; Ovidio et al. 2002). In the future, combined studies using biotelemetry and visual observations while snorkeling could improve the knowledge on the relation between social status and mobility in Atlantic salmon parr as well as of motivations controlling movement and space use in Atlantic salmon parr. The classical view of the mosaic distribution of territories was not confirmed; instead parr had overlapping home ranges as it has been observed elsewhere (Stradmeyer and Thorpe 1987; Armstrong et al. 1999; Martin-Smith and Armstrong 2002; Økland et al. 2004).

Finally, the subsampling of our data to consider only two or six locations per day revealed important changes in the estimation of the home ranges in comparison with our intensive tracking method. Even at the expense of increasing the autocorrelation between observations, the intense survey on a small number of fish allowed an increase of the precision and accuracy of home ranges estimates (deSolla et al. 1999). By contrast, increasing the number of fish observed at lower frequency but over a longer period of time improves knowledge on the diversity of individual parr behavior and on their consistency over time. However, the comparison of studies relying on different relocation frequencies could generate confusing interpretations (Ovidio et al. 2000).

Acknowledgements. Financial support for this study was provided by the Ministère des Relations Internationales du Québec et le programme de coopération Wallonie-Bruxelles/Québec (Communauté française de Belgique), the Natural Sciences and Engineering Research Council of Canada, the Canada Research Chair program and the Ministry of Walloon Region (DGRNE-Meuse Salmon Project). J.C. Philippart is a Research Associate from the Belgian FNRS. Special thanks to Claudine Boyer, Damien Sonny, Julie Thérien and Julien Mols for their efficient and competent assistance during the fieldwork. We also thank the 'Corporation des rivières Matapédia et Patapédia and Gaëtan Lavoie for well-organized logistic support and Pierre Hallot for the FishTracker software. The authors also thank anonymous reviewers for constructive comments.

\section{References}

Adams, N.S., Rondorf, D.W., Evans, S.D., Kelly, J.E., Perry, R.W. 1998, Effects of surgically and gastrically implanted radio transmitters on swimming performance and predator avoidance of juvenile chinook salmon (Oncorhyncus tshawytscha). Can. J. Fish. Aquat. Sci. 55, 781-787.

Armstrong, J.D., Braithwaite, V.A., Huntingford, F.A. 1998, Spatial strategies of wild Atlantic salmon parr: Exploration and settlement in unfamiliar areas. J. Anim. Ecol. 66, 203-211.

Armstrong, J.D., Huntingford, F.A., Herbert, N.A. 1999, Individual space use strategies of wild juvenile Atlantic salmon. J. Fish Biol. 55, 1201-1212.

Armstrong, J.D., Shackley, P.E., Gardiner, R. 1994, Redistribution of juvenile salmonid fishes after localized catastrophic depletion. J. Fish Biol. 45, 1027-1039.

Berland, G., Nickelsen, T., Heggenes, J., Økland, F., Thorstad, E.B., Halleraker, J., 2004, Movements of wild Atlantic salmon parr in relation to peaking flows below a hydropower station. River Res. Appl. 20, 957-966.
Brown, R.S., Cooke S.J., Anderson W.G, McKinley, R.S., 1999, Evidence to challenge the " $2 \%$ " rule for biotelemetry. N. Am. J. Fish. Manage. 19, 867-871.

Connors, K.B., Scruton, D., Brown, J.A., McKinley, R.S. 2002, The effects of surgically-implanted dummy transmitters on the behaviour of wild Atlantic salmon smolts. Hydrobiologia 483, 231-237.

deSolla, S.R., Bonduriansky, R., Brooks, R.J. 1999, Eliminating autocorrelation reduces biological relevance of home range estimates. J. Anim. Ecol. 68, 221-234.

Erkinaro, J., Gibson, R.J., 1997, Interhabitat migration of juvenile Atlantic salmon in a Newfoundland river system, Canada.J. Fish Biol. 51, 373-388.

Garcia de Leaniz, C. 1989, Site fidelity and homing of Atlantic salmon parr in a small stream. In: Brannon, E., Jonsson B. (Eds.), Salmonid migration and distribution. Seattle: School of Fisheries, University of Washington.

Gibson, R.J., 1993, The Atlantic salmon in fresh water: Spawning, rearing and production. Rev. Fish Biol. Fish. 3, 39-73.

Hesthagen, T., 1990, Home range of juvenile Atlantic salmon, Salmo salar, and brown trout, Salmo trutta, in a Norwegian stream. Freshw. Biol. 24, 63-67.

Hooge, P.N., Eichenlaub, B. 2000, Animal movement extension to Arcview. ver. 2.0 Alaska Science Center - Biological Science Office, U.S. Geological Survey, Anchorage, AK, USA.

Huntingford, F.A., Braithwaite, V.A., Armstrong, J.D., Aird, D., Joiner, P. 1998, Homing in juvenile salmon in response to imposed and spontaneous displacement - experiments in an artificial stream. J. Fish Biol. 53, 847-852.

Kalleberg, H. 1958, Observations in a stream tank of territoriality and competition in juvenile Atlantic salmon and trout (Salmo salar L. and S. trutta L.). Insitute of Freshwater Research Drottingholm Report 39, 55-98.

Keenleyside, M.H.A., Yamamoto, F.T., 1961, Territorial behaviour of juvenile Atlantic salmon (Salmo salar L.). Behaviour 19, 139-169.

Lacroix, G.L., Knox, D., McCurdy, P. 2004, Effects of implanted dummy acoustic transmitters on juvenile Atlantic salmon. Trans. Am. Fish. Soc. 133, 211-220.

Lucas, M. C., Baras, E. 2001, Migration of Freshwater Fishes. Oxford: Blackwell Scientific Publications.

Martin-Smith, K.M., Armstrong, J.D. 2002, Growth rates of wild stream-dwelling Atlantic salmon correlate with activity and sex but not dominance. J. Anim. Ecol. 71, 413-423.

Maclean, A., Huntingford, F.A., Ruxton, G.G., Morgan, I.J., Hamilton J., Armstrong, J.D., 2005, Testing the assumptions of the ideal despotic distribution with an unpredictable food supply: experiments in juvenile salmon. J. Anim. Ecol. 74, 214-225.

Murchie, K.J., Cooke, S.J., Schreer, J.F., 2004, Effects of radiotransmitterantenna length on swimming performance of juvenile rainbow trout. Ecol. Freshw. Fish. 13, 312-316. 
Økland, F., Thorstad, E.B., Næsje, T.F. 2004, Is Atlantic salmon production limited by number of territories? J. Fish Biol. 65, 1047-1055.

Ovidio, M., Philippart, J.C., Baras, E. 2000, Methodological bias in home range and mobility estimates when locating radio-tagged trout, Salmo trutta, at different time intervals. Aquat. Living Resour. 13, 449-454.

Ovidio, M., Baras, E., Goffaux, D., Giroux, F., Pilippart, J.C. 2002, Seasonal variations of activity pattern of brown trout (Salmo trutta) in a small stream, as determined by radio-tracking. Hydrobiologia, 470, 195-202.

Robertson, M.J., Scruton, D.A., Brown, J.A. 2003, Effects of surgically implanted transmitters on swimming performance, food consumption and growth of wild Atlantic salmon parr. J. Fish Biol. 65, 1070-1079.

Robertson, M.J., Pennell, C.J., Scruton, D.A., Robertson, G.J., Brown, J.A. 2004, Effect of increased flow on the behaviour of Atlantic salmon parr in winter. J. Fish Biol. 65, 1070-1079.

Roussel, J.M., Cunjak, R.A., Newbur, R., Caissie, D., Haro, A. 2004, Movements and habitat use by PIT-tagged Atlantic salmon parr in early winter: the influence of anchor ice. Freshw. Biol. 48, 1026-1035.
Roussel, J.M., Haro, A., Cunjak, R.A. 2000, Field test of a new method for tracking small fishes in shallow rivers using passive integrated transponder (PIT) technology. Can. J. Fish. Aquat. Sci. 57, 1326-1329.

Saunders, R.L., Gee, J.H. 1964, Movements of young Atlantic salmon in a small stream. . Fish. Res. Board Can. 21, 27-36.

Scruton, D.A., Ollerhead, L.M.N., Clarke, K.D., Pennell, C., Alfredsen, K., Harby, A., Kelly, D. 2003, The behavioural response of juvenile Atlantic salmon (Salmo salar) and brook trout (Salvelinus fontinalis) to experimental hydropeaking on a Newfoundland (Canada) River. Riv. Res. Appl. 19, 577-587.

Silvermann, B.H. 1986, Density Estimation for Statistics and Data Analysis location: Chapman and Hall.

Steingrimsson, S.O., Grant, J.W.A. 1999, Allometry of territory size and metabolic rate as predictors of self-thinning in young-of-theyear Atlantic salmon. J. Anim. Ecol. 68, 17-26.

Stradmeyer, L., Thorpe, J. 1987, Feeding behaviour of wild Atlantic salmon, Salmo salar L., parr in mid- to late summer in a Scottish river. Aquac. Fish. Manage. 18, 33-49.

Worton, B.J. 1989, Kernel methods for estimating the utilization distribution in home-range studies. Ecology 70, 164-168. 